\title{
Nutritious mushroom protein crisp - healthy alternative to starchy snack
}

\author{
Venkatesh Balan ${ }^{1 *}$ D, Dianne Novak², William Knudson², A. Daniel Jones ${ }^{3}$, Fabiola Maria Iñiguez-Franco4, \\ Rafael Auras ${ }^{4}$, Sungeun $\mathrm{Cho}^{5}$, Amanda Rodgers ${ }^{1}$ and Bryan Ubanwa ${ }^{1}$
}

\begin{abstract}
Global salty snacks category had reached USD 137 billion in sales in 2018. Due to growing health concerns and awareness, consumers are looking for healthy snack choices by avoiding ingredients such as fat, sugar, cholesterol, and sodium and selecting baked and salt free multigrain chips. A sizable number of consumers are concerned about snack nutrition and look for quality ingredients and minimally processed foods called as "Good Health Snack $(\mathrm{GHS})^{\prime \prime}$. In this work, we present the development of method of producing and testing mushrooms protein crisps (MPC), a healthy alternative to conventional starchy snacks that are rich in protein, nutraceutical compounds, minerals, vitamin, dietary fiber, and immunity inducing beta-glucans. The methods of producing MPC with different seasoning and hydrolyzed protein, calorie, nutritional and chemical composition, consumer response, shelf life after packing and market analysis are described. These systematic studies will help to market potential of this product which is a healthy alternative to other calorie rich snacks sold in the market benefiting the consumers.
\end{abstract}

Keywords: Healthy diet, Mushroom, Starch, Obesity, Diabetes, Cholesterol

\section{Introduction}

Global salty snack industry comprising of chips, pretzels, nuts, and seeds is an over $\$ 137$ billion industry in 2018 according to market researchers (Zion Research 2016; Businesswire 2020; Muhammed et al. 2020). Among the salty snacks, the chips (either sliced or extruded dough comprising of different ingredients) occupy one third of the market size filled with condiments that are saturated with salty, starchy, fat rich, and calorie-dense foods that have little to no nutritional benefit towards human health (Ouhtit et al. 2014; Zaheer and Akhtar 2016). Most prominent salty snack include potato chips (34\%) and tortilla chips (23\%), followed by other salty snacks (18\%) and popcorn, pretzels, corn, cheese snacks (8\%) (Fig. 1) (Murakami and Livingstone 2016). Consuming these snacks above the recommended portion size, combined with no proper diet and exercise, can lead to

\footnotetext{
* Correspondence: vbalan@uh.edu

1Department of Engineering Technology, Biotechnology Program, College of

Technology, University of Houston, TX 77479 Sugar Land, USA

Full list of author information is available at the end of the article
}

detrimental health concerns, such as high blood pressure, obesity, and diabetes, which are leading causes for global deaths (Rios-Hoyo and Gutierrez-Salmean 2016; Aghayan et al. 2019; Pérez-Gimeno et al. 2020, Greener 2019).

In the past few years, healthy snacks using whole grain and vegetable flour are finding marketplace, such as multigrain chips, beans (pinto or black), and kale in combination with sunflower and sesame seeds. These snacks are either fried or baked and sold in the market in airtight bags for longer shelf life. Though these healthier snacks contain desirable amounts of fiber and protein, they still contain considerable starch, fat, and salt (Hess et al. 2016). Most of the mixed vegetable and mushroom snacks sold in markets have become popular among the public recently and are considered as healthier snack alternative, yet these vegetables are fried in oils, adding extra calories and trans-fat in consumers' diet (Cho and Risvi 2010). Meanwhile, due to growing health concerns and awareness, consumers are also attempting to make healthy snack choices with reduced fat, sugar,

(c) The Author(s). 2021 Open Access This article is licensed under a Creative Commons Attribution 4.0 International License, which permits use, sharing, adaptation, distribution and reproduction in any medium or format, as long as you give appropriate credit to the original author(s) and the source, provide a link to the Creative Commons licence, and indicate if changes were made. The images or other third party material in this article are included in the article's Creative Commons licence, unless indicated otherwise in a credit line to the material. If material is not included in the article's Creative Commons licence and your intended use is not permitted by statutory regulation or exceeds the permitted use, you will need to obtain permission directly from the copyright holder. To view a copy of this licence, visit http://creativecommons.org/licenses/by/4.0/. 

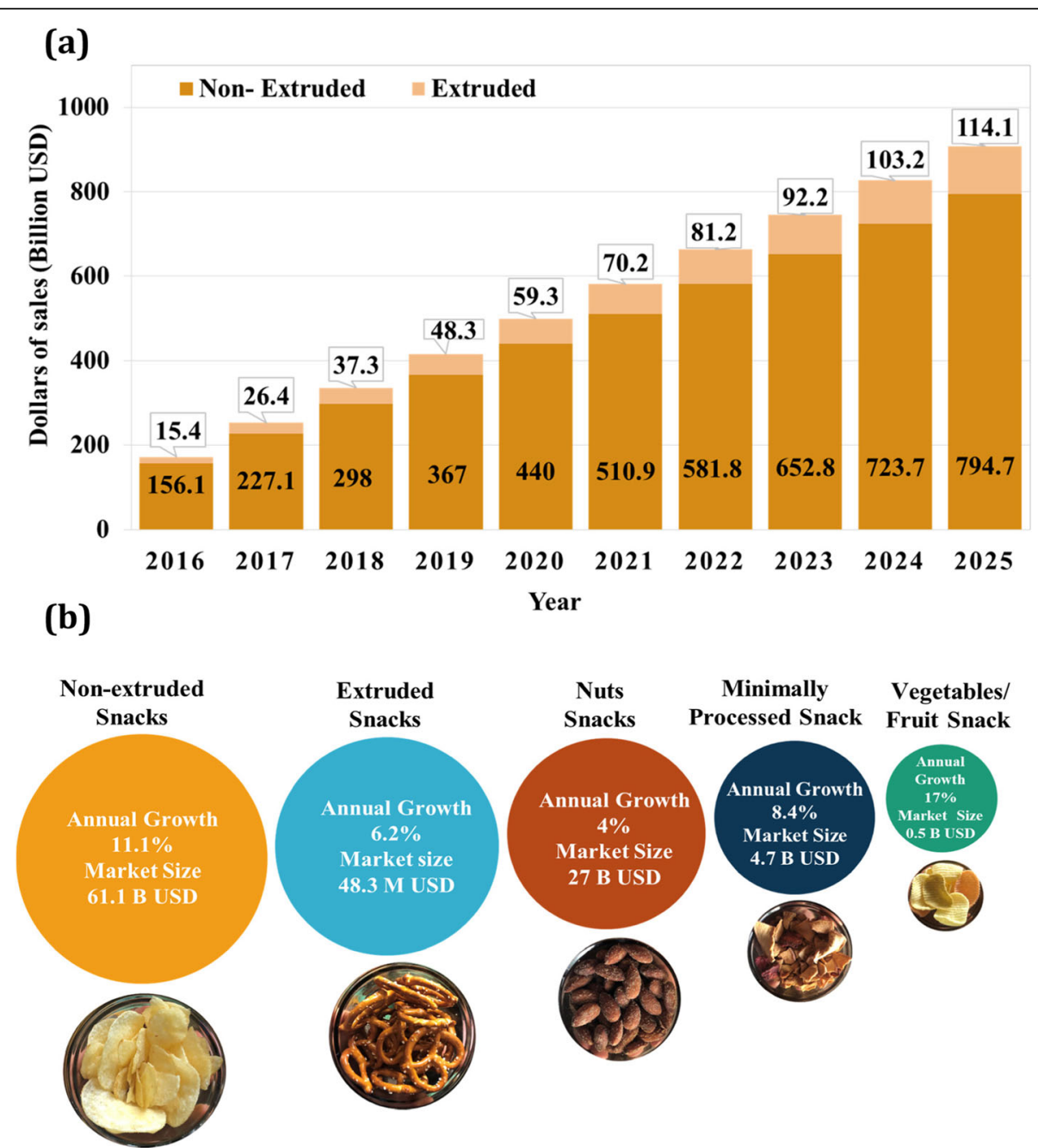

Fig. 1 Global snack market and their annual growth. Here, a non-extruded and extruded snack market size for the past 4 years and projections for the next 5 years and $\mathbf{b}$ Different snack categories, their market size and annual growth rate in the year 2018

cholesterol, and sodium and are increasingly selecting baked multigrain chips (Agrahar-Murugkar et al. 2018).

Market analysis shows that consumers are concerned about nutrition and look for quality ingredients and minimally processed foods known as "Good Health Snack (GHS)" (Ilkay 2013). These GHS snacks are produced using sliced vegetable (e.g., beet, carrot, and pumpkins) blanched, seasoned, and freeze-dried. The Compound Annual Growth Rate (CAGR) is $2.8 \%$ in the recent years, meanwhile the demand for GHS is seeing growth in the double-digit range (Fig. 1) (CSP daily news 2016). The USDA has also emphasized the importance of healthy snacks through its nutrition standards for competitive foods sold outside the federal reimbursable school meal program "Smart Snacks in School" (USDA 2016). The expectation is to raise use of snacks containing less starch, fat and sodium, and higher content of protein, dietary fiber, essential minerals, vitamins, nutraceutical compounds, and healthy fiber rich carbohydrates. Thus, snack manufacturers are experimenting with new vegetables that has health promoting nutraceutical antioxidants and minerals (Chatterjee 2016; Valverde et al. 2015).

Mushrooms are fruiting body of edible fungus that can also be used to produce snacks due to their health benefits (Roupas et al. 2012; Rathore et al. 2017; RonceroRamos and Delgado-Andrade 2017; Carrasco-González et al. 2017). Different edible mushrooms are commercially cultivated around the world, including Agaricus (button), Cremini, Shiitake, Maitake, Portobello, Enoki, Wood Ear, Oyster (including different varieties) and Milky white, etc. (Marshall and Nair 2009; Subbiah and Balan 2015). Mushrooms contain umami flavor (meaty, broth-like, or savory taste, which is unique when compared to the four tastes namely, sweet, sour, salty, and bitter) have several beneficial properties, including low 
caloric content, contain complex carbohydrates, are cholesterol-free, and low in sodium and saturated fat. Mushrooms are also known to improve human health since they are good source of essential minerals such as selenium and potassium; health promoting vitamins, protein, fiber, and nutraceutical compounds, which are anticancer, antitumor, immune system enhancer, antibacterial and cholesterol lowering agents. Mushrooms are starch free and contain soluble and insoluble dietary fiber (DF), monosaccharides, disaccharides, sugar alcohols, polysaccharides such as beta-glucans, glycogen, and chitin (Poddar et al. 2012; Ghosh 2016; Mattila et al. 2002). Several dietetic associations have recommended a daily DF intake of $36 \mathrm{~g} /$ day for adult men and $28 \mathrm{~g} /$ day for adult women (Lattimer and Haub 2010), which can be provided by mushrooms. Some of the health benefits of DF is that it aids lowers cholesterol levels, control blood sugar, and support bowel health, maintaining a lean body mass and lowering the risk of diabetes, heart disease and some types of cancer (Li and Komarek 2017).

Mushroom snacks are more prevalent for consumers in Southeast Asian countries, and they are made using mostly button, shitake, and oyster mushrooms. These snacks are getting popular in western countries. There are five common methods used to produce snacks by processing mushrooms or using mushroom ingredients. They include: (i) A combination of blanching mushroom slices, vacuum frying followed by centrifugal de-oiling and seasoning (Ren et al. 2010; Yanbin et al. 2014), (ii) Making a chip from a dough comprising of dry mushroom powder, protein (from shrimp or animal protein), starch (either wheat, soy protein meal or potato), seasoning followed by puffing using microwave or baked using high temperature oven or fried and de-oiling (Zhihui et al. 2012; Shengrong et al. 2015; Zhinian 2013; Chao et al. 2013), (iii) producing seasoned puffed mushroom chips using a combination of far infrared and vacuum microware using freeze dried mushrooms (Ning et al. 2012; Qiuhui et al. 2014; Hengsheng et al. 2013), (iv) mushroom slices boiled in auxiliary liquid followed by removing the moisture using freeze drying (Chune 2013; Zinian 2013) and (v) using mushroom powder in different ratios as seasoning ingredient in potato or grain chips prior to processing and packing (Bingqiang 2015).

In this work, we present a new minimal processing method of producing nutrition rich mushroom protein crisps (MPC) using sliced Pleuorotus eryngii (king oyster) mushrooms, hydrolyzed proteins, and different seasonings for the first time. Consumer taste profile analysis using 80 participants showed that MPC have an excellent flavor profile and could be a viable alternative to salty, starchy snacks, promoting good health and satisfy all the GHS requirements. Detailed composition of
MPC, packaging, shelf life, and market analysis are also discussed. Adding hydrolyzed peptides to the MPC helped to reduce browning and added sensory quality. MPC containing externally added hydrolyzed peptides which is expected to provide physiological health benefits to several organ in the body including skin, hair, muscle, joints, eye, gut, heart, and brain. Other systemic health benefits to immune, nervous, cardiovascular, and gastrointestinal system are expected (Gupta et al. 2018).

\section{Materials and methods}

\section{Raw materials}

King oyster mushrooms, all the seasonings such as crushed salt, pepper powder, Nacho cheese, Jalapeno powder, cocoa powder, chili powder, and turmeric powder (Kroger brand) were purchased from local groceries in East Lansing, MI and used in different combinations. Two premixed seasoning in this study onion-garlic (GOYA brand) and sugar-cinnamon premix (Kroger brand) to flavor MPC were used as it is from the store without modifying their composition. Different source of protein power, such as peas (hydro Pea); rice and egg white (Judee's); soybean and whey (Bulk supplements) and hydrolyzed collagen (Amandean) was purchased from Amazon and stored in sealed pack at room temperature until further use.

\section{Method of preparation of MPC}

Fresh large diameter king oyster mushrooms were prepared to produce slices using an automatic Eurodib HLC300 (Eurodib Corp, NY) vegetable processing machine. The following steps were used to produce MPC with consistent quality: (i) surface dirt was removed using running water and cleaned MPC were stored in a wire mesh bin for few minutes until the water drains out, (ii) the mushrooms were sliced and placed in a pan, (iii) hydrolyzed plant/animal protein (up to $5 \%$ of dry weight of mushroom) and different seasoning (up to $2 \%$ of dry weight of mushroom) were added, and (iv) the mushroom slices were baked in an oven for a defined amount of time without adding any oil or fat. The baked MPC were then allowed to cool down and stored in dry glass bottle, flushed with nitrogen gas to maintain crispy texture for long time storage.

\section{Effect of temperature on MPC taste and appearance}

Temperature during baking plays a key role in retaining the phenolic components and flavoring compounds that gave good taste while consuming the mushroom crisps. We varied the temperature $\left(60-120^{\circ} \mathrm{C}\right)$ in an electrical oven, while baking the mushroom crisp. To strike a balance between the desirable sensory qualities and the textural properties to ensure mushroom crispiness that 
would be acceptable to consumers, we selected the right baking temperature for future experiments.

\section{Determination of composition and nutrition facts}

Freshly produced MPC without any seasoning was sent to Great Lakes Scientific Inc., Stevensville, MI to determine the composition. Different pieces were analyzed using standard methods established by the Association of Official Agricultural Chemists (AOAC), and they are given in bracket followed by the edition number where the full procedure can be found. Total carbohydrate was calculated using the formula $(100 \%-\%$ fat $+\%$ protein $+\%$ moisture $+\%$ ash $)$, dietary fiber (AOAC 985.29 17th ed.), free sugars (AOAC 982.14 and using High Performance Liquid Chromatography (HPLC) using reported procedure) (Niekerk and Macrae 1988), starch (AOAC 2014.10), total fat (AOAC 922.06 17th ed.), different types of fat (saturated fat, polyunsaturated, monounsaturated and trans-fat) (AOAC 969.33 \& 963.22 17th ed.), cholesterol (AOAC 976.26 17th ed.), protein (AOAC 923.04 17th ed.), Vitamins A (AOAC 992.04 17th ed. and using reported procedure (Analyst 1985), Vitamin B6 (AOAC 961.15, 985.32, 960.46), vitamin D (AOAC 995.05), Vitamin E (Speek et al. 1985), Niacin (Vitamin $B_{3}$ ) (AOAC 944.13, 960.46), folic acid (AOAC 2011.06) and other Vitamins such as Thiamin (Vitamin $B_{1}$ ) and Riboflavin (Vitamin $\mathrm{B}_{2}$ ) (AOAC 942.43, 970.65, 981.15), minerals such as sodium (AOAC 966.16 17th ed.), selenium (USP 233), potassium (AOAC 975.03 17th ed.), phosphorus (AOAC 958.01) and other minerals such as calcium, iron, copper, magnesium phosphorus (AOAC 985.35 17th ed.). The composition analysis was done in triplicate and standard deviations were < $8 \%$ for vitamins and dietary fibers and $<5 \%$ for other components. Details about the composition of MPC can be found in Table 1. Calories per $100 \mathrm{~g}$ of MPC were calculated using $4 \mathrm{cal}$ per $\mathrm{g}$ protein/carbohydrates and $9 \mathrm{cal}$ per $\mathrm{g}$ fat.

\section{Effect of drying time}

Mushrooms consist of $80-85 \%$ moisture and took considerable amount of time to bake the mushroom at a given temperature. Using regular oven without vacuum generated considerable amount of condensed water on the door. We also evaluated spiral oven at MSU Food Processing and Innovation Center and found that good quality MPC could be produced continuously in few hours. These small batches ran in $\sim 20$ min or less cycles, depending on trays in the oven.

\section{Sensory evaluation}

Consumer testing was conducted using the sensory evaluation lab in the Department of Food Science and Human Nutrition at Michigan State University. The panelist participated in this study their gender, age, education, and household income are given in Table 2. The study protocol was approved by the Institutional Review
Table 1 Composition of the mushroom protein crisp

\begin{tabular}{|c|c|}
\hline Different Components and Calories/100 g & Amount \\
\hline Calories & 367 \\
\hline Total Fat & $1.3 \mathrm{~g}$ \\
\hline Saturated Fat & $0.2 \mathrm{~g}$ \\
\hline Trans Fat & $<0.1 \mathrm{~g}$ \\
\hline Polyunsaturated Fat & $1.0 \mathrm{~g}$ \\
\hline Monounsaturated Fat & $0.1 \mathrm{~g}$ \\
\hline Total Carbohydrates & $58.6 \mathrm{~g}$ \\
\hline Starch & $<0.1 \mathrm{~g}$ \\
\hline Sugar & $5.6 \mathrm{~g}$ \\
\hline Added Sugar & $0 \mathrm{~g}$ \\
\hline Dietary Fiber & $31.4 \mathrm{~g}$ \\
\hline Cholesterol & $<1.0 \mathrm{mg}$ \\
\hline Protein & $30.3 \mathrm{~g}$ \\
\hline Water (Moisture) & $4.4 \mathrm{~g}$ \\
\hline Vitamins & Amount \\
\hline Vitamin A & $<0.1 \mathrm{mcg}$ \\
\hline Vitamin B1 & $0.1 \mathrm{mg}$ \\
\hline Vitamin B2 & $1.50 \mathrm{mg}$ \\
\hline Vitamin B3 & $32.0 \mathrm{mg}$ \\
\hline Vitamin B6 & $0.35 \mathrm{mg}$ \\
\hline Vitamin B9 & $367 \mathrm{mcg}$ \\
\hline Vitamin D & $<1.0 \mathrm{mcg}$ \\
\hline Vitamin E & $0.54 \mathrm{mg}$ \\
\hline Minerals & Amount \\
\hline Magnesium & $110 \mathrm{mg}$ \\
\hline Selenium & $<100 \mathrm{mcg}$ \\
\hline Copper & $0.53 \mathrm{mg}$ \\
\hline Phosphorus & $556 \mathrm{mg}$ \\
\hline Sodium & 90 mg \\
\hline Potassium & $2.5 \mathrm{~g}$ \\
\hline Iron & $3.2 \mathrm{mg}$ \\
\hline Calcium & $2.0 \mathrm{mg}$ \\
\hline
\end{tabular}

Key to Units of Measures: Here, $\mathrm{g}$ - gram, $\mathrm{mg}$ - milligram, mcg - microgram; Standard deviations $<8 \%$ for vitamins and dietary fibers; $<5 \%$ for others. Other vitamins B12 and C are present in King Oyster mushrooms but was not quantified in MPC. Mushroom Protein Crisp is a baked product, and no fat was used in the process

Board of Michigan State University (East Lansing, MI, USA). Written informed consent was obtained from all participants, and SIMS 2000 software (SIMS Sensory Software, Morristown, NJ, USA) was used to create and administer the questionnaire. Among various seasonings, garlic- onion, sugar-cinnamon seasoning was compared with plain (control) MPC. Three batches of MPC were prepared about $1 \mathrm{~kg}$ each under the supervision of a chef in a commercial kitchen in Lansing, MI. Two of the three batches were seasoned using garlic -onion, sugar- 
Table 2 Gender, age, education, and household income of panelist

\begin{tabular}{|c|c|c|}
\hline Gender & $\mathrm{N}$ & $\%$ \\
\hline Male & 8 & 22.5 \\
\hline Female & 62 & 77.5 \\
\hline Total & 80 & 100.0 \\
\hline Age & $\mathrm{N}$ & $\%$ \\
\hline $18-29$ & 39 & 48.8 \\
\hline $30-39$ & 19 & 23.8 \\
\hline $40-49$ & 14 & 17.5 \\
\hline $50-59$ & 4 & 5.0 \\
\hline $60-69$ & 4 & 5.0 \\
\hline Total & 80 & 100.0 \\
\hline Education & $\mathbf{N}$ & $\%$ \\
\hline Middle school or less & 0 & 0.0 \\
\hline High school & 8 & 10.0 \\
\hline 2-year college & 5 & 6.3 \\
\hline 4-year college & 34 & 42.5 \\
\hline Graduate school & 33 & 41.3 \\
\hline Total & 80 & 100.0 \\
\hline Household Income & $\mathbf{N}$ & $\%$ \\
\hline Under $\$ 15,000$ & 14 & 17.5 \\
\hline$\$ 15,000-\$ 24,999$ & 16 & 20.0 \\
\hline$\$ 25,000-\$ 34,999$ & 7 & 8.8 \\
\hline$\$ 35,000-\$ 44,999$ & 8 & 10.0 \\
\hline$\$ 45,000-\$ 54,999$ & 9 & 11.3 \\
\hline$\$ 55,000-\$ 64,999$ & 4 & 5.0 \\
\hline$\$ 65,000-\$ 74,999$ & 3 & 3.8 \\
\hline$\$ 75,000-\$ 84,999$ & 3 & 3.8 \\
\hline$\$ 85,000-\$ 94,999$ & 3 & 3.8 \\
\hline More than $\$ 94,999$ & 13 & 16.3 \\
\hline Total & 80 & 100.0 \\
\hline
\end{tabular}

All the panelist who took part in this study were untrained

cinnamon seasoning and plain MPC was used as control. All samples were prepared and stored in a sealed bottle the previous day before the sensory evaluation. For each participant, 2 pieces of each sample (plain, garlic-onion, sugar-cinnamon) were presented in a 4-oz $(118-\mathrm{mL})$ soufflé cup identified with a 3-digit code. Water and crackers were provided as palate cleansers. Participants were asked to evaluate each sample with respect to appearance, flavor, texture, and overall liking on 9-point hedonic scales ranging from 1 (dislike extremely) to 9 (like extremely). In addition, 4 sensory attributes, that is, surface color, overall flavor, vegetable flavor, seasoning flavor (for seasoned samples) and crispness, of each sample were evaluated on 5-point "Just-About-Right" scales $(1=$ much too light $/$ weak/soggy, $3=$ just about right, $5=$ much too dark/strong/crisp). After the sample-related questions, participants were asked for the demographic questions including age, gender, education status, annual income, and consumption frequency of chips and vegetable.

\section{Incorporating proteins and hydrolyzed protein in MPC}

A minimum protein requirement in the snack should be $>20 \%$ to call them as protein snack. The protein content in MPC was increased by externally adding plant and animal proteins from different sources. Hydrolyzed plant protein (e.g., pea and soy) and other animal protein (e.g., milk and egg white) did alter the flavor of MPC. Since there are sizable amount of carbohydrate, fat, mineral and other ingratiates in most of the commercial protein supplements, they mask the flavor of the mushrooms. By incorporating hydrolyzed animal protein (e.g., collagen up to $5 \%$ of the mushroom dry weight) obtained from commercial sources, we could increase the protein content without altering flavor of the original mushrooms. Appearance of mushroom protein crisp produced by this method was analogous to the mushroom crisp without adding any external protein supplementation.

\section{Mass spectrometry measurements of MPC constituents} MPC samples were extracted in HPLC-grade acetone $(10 \mathrm{mg} / \mathrm{mL})$ for $24 \mathrm{~h}$ at room temperature for evaluation of flavor chemicals such as Maillard products such as pyrazines and imidazole's, explore formation of offflavor components derived from processing, and to evaluate for the presence of agrochemicals. Two acetone blank injections were made between each MPC extract to minimize carryover between samples. Analyses extracts were performed using an Agilent 5975C mass spectrometer interfaced to an Agilent 6890B gas chromatograph (GC-MS). A $30 \mathrm{~m}$ VF-5 ms column (Agilent, Palo Alto, CA; $0.25 \mathrm{~mm}$ I.D., $0.25 \mu \mathrm{m}$ film with $10 \mathrm{~m}$ retention gap) was used for analyses. Column temperature was programmed from 100 to $250^{\circ} \mathrm{C}$ at $10^{\circ} \mathrm{C}$ /minute with a final 3-min hold at $250^{\circ} \mathrm{C}$. Injections of $1.0 \mu \mathrm{L}$ volumes were made using a 20:1 split ratio and injector temperature of $250{ }^{\circ} \mathrm{C}$. Electron ionization mass spectra $(70 \mathrm{eV})$ were acquired by scanning $\mathrm{m} / \mathrm{z} 30-300$ at 5 spectra/second (Chen et al. 2018; Qinzhu et al. 2017). Compounds were annotated based on searching of mass spectra against the NIST 2011 mass spectrum database using ChemStation software.

\section{MPC storage experiment}

The storage of two different kinds of prepared MPC was evaluated (plain chips and garlic -onion flavored chips) after 3- and 6-months storage. Metallized heat seal bags (thickness $=1.9 \mathrm{~mm}$ ) obtained from Clear Bags (El Dorado Hills, CA, USA) were used to pack $15 \mathrm{~g}$ of the 
mushroom chips. A vacuum packaging machine (Multivac, Inc., Kansas, MO, USA) was used to seal the bags under $\mathrm{N}_{2}$ gas with a gas pressure for the flush of -140 mbar. The storage of the samples was conducted in two different conditions: (i) $23^{\circ} \mathrm{C}, 50 \%$ relative humidity (RH), and (ii) $37.8^{\circ} \mathrm{C}, 85 \% \mathrm{RH}$. Two different chambers were used for each condition. However, for first condition, magnesium nitrate saturated aqueous salt solution (Jade Scientific, Canton, MI, USA) deposited in buckets was used to reach $50 \% \mathrm{RH}$. Four bags of plain and garlic-onion seasoned chips at each condition were stored (See Figures S1 and S2).

\section{MPC moisture analysis}

The moisture of the samples before and after storage (i.e., 3- and 6-months) was analyzed using a MX-50 moisture analyzer (A\&D, Elk Grove, IL, USA). Approximate, $5 \mathrm{~g}$ of sample were used for each measurement. The measurements were conducted in duplicate.

\section{Package headspace $\mathrm{O}_{2}$ and $\mathrm{CO}_{2}$ analysis}

After the sealing of the bags with the mushroom chip samples (i.e., plain chips and garlic -onion seasoned chips), the $\mathrm{O}_{2}$ and $\mathrm{CO}_{2}$ in the headspace of the bag was analyzed using a 6600-headspace oxygen/carbon dioxide analyzer (Illinois Instruments, Inc., Johnsburg, IL, USA). Just before being measured, bags were removed from storage and an adhesive septum (Illinois Instruments, Johnsburg, IL, USA) was adhered to the bag surface. The headspace composition of the bags was measured in duplicate, and the result reported as air composition as expected.

\section{Statistical analyses}

One-way analysis of variance (ANOVA) was conducted to compare average values of the physicochemical and microbiological results using the Tukey HSD test $(p<$ 0.05 ) using JMP ${ }^{\star} 13$ (Cary, NC, USA) statistical software. Using this software, differences among storage time could be determined.

\section{Market analysis}

The market potential of MPC, potential consumer interest, potential niches, and other considerations were analyzed. Data for this analysis were derived from published sources as well as the results of the MSU consumer acceptance study.

\section{Nutritional facts}

The analytic tests performed by Great Lakes Scientific, to determine the nutrient values of the MCP, has provided the data necessary to create a Nutrition Facts panel for consumer review. This information can be viewed in Table 3. These results have shown per the recommended Federal Drug Administration (FDA) serving of $28 \mathrm{~g}$, to have $100 \mathrm{cal}$ with an additional healthful profile of being fat-free, cholesterol free, very-low sodium and high fiber food per FDA. The MPC also provide a variety of additional vitamin and minerals as outlined in the Table 1, which are discussed within this document for its beneficial contribution to health.

Table 3 Nutritional facts comparison of popular salty snacks sold in the market and mushroom protein crisp. Percentage detail value of each component is provided next their quantity

\begin{tabular}{|c|c|c|c|c|c|c|c|c|}
\hline \multirow[b]{2}{*}{ Serving Size } & \multicolumn{2}{|c|}{$\begin{array}{l}\text { Doritos nacho } \\
\text { cheese flavor }\end{array}$} & \multicolumn{2}{|c|}{ Cheetos cheese flavor } & \multicolumn{2}{|c|}{$\begin{array}{l}\text { Lays classic } \\
\text { potato chips }\end{array}$} & \multicolumn{2}{|c|}{$\begin{array}{l}\text { Mushroom } \\
\text { protein crisp } \\
\text { (Plain/un-seasoned) }^{a}\end{array}$} \\
\hline & \multicolumn{2}{|c|}{ (28 g 12 chips) } & \multicolumn{2}{|c|}{ (28g $\sim 21$ pieces) } & \multicolumn{2}{|c|}{ (28 g 15 chips) } & \multicolumn{2}{|c|}{ (28 g 30 chips) } \\
\hline Calories & \multicolumn{2}{|l|}{150} & \multicolumn{2}{|l|}{160} & \multicolumn{2}{|l|}{160} & \multicolumn{2}{|l|}{100} \\
\hline Calcium & $40 \mathrm{mg}$ & $2 \%$ & $10 \mathrm{mg}$ & $0 \%$ & $10 \mathrm{mg}$ & $0 \%$ & $0 \mathrm{mg}$ & $0 \%$ \\
\hline Total Carbohydrate & $18 \mathrm{~g}$ & $6 \%$ & $15 \mathrm{~g}$ & $6 \%$ & $15 \mathrm{~g}$ & $6 \%$ & $16 \mathrm{~g}$ & $6 \%$ \\
\hline Cholesterol & $0 \mathrm{~g}$ & $0 \%$ & $0 \mathrm{mg}$ & $0 \%$ & $0 \mathrm{mg}$ & $0 \%$ & $0 \mathrm{mg}$ & $0 \%$ \\
\hline Total Fat & $8 \mathrm{~g}$ & $10 \%$ & $10 \mathrm{~g}$ & $13 \%$ & $10 \mathrm{~g}$ & $13 \%$ & $0 \mathrm{~g}$ & $0 \%$ \\
\hline Saturated fat & $1 \mathrm{~g}$ & $6 \%$ & $1.5 \mathrm{~g}$ & $8 \%$ & $1.5 \mathrm{~g}$ & $7 \%$ & $0 \mathrm{~g}$ & $0 \%$ \\
\hline Trans Fatty Acids & \multicolumn{2}{|l|}{$0 \mathrm{~g}$} & \multicolumn{2}{|l|}{$0 \mathrm{~g}$} & \multicolumn{2}{|l|}{$0 \mathrm{~g}$} & \multicolumn{2}{|l|}{$0 \mathrm{~g}$} \\
\hline Iron & $0.3 \mathrm{mg}$ & $0 \%$ & $0.4 \mathrm{mg}$ & $2 \%$ & $0.6 \mathrm{mg}$ & $2 \%$ & $1 \mathrm{mg}$ & $6 \%$ \\
\hline Dietary Fiber & $1 \mathrm{~g}$ & $4 \%$ & $<1 \mathrm{~g}$ & $3 \%$ & $1 \mathrm{~g}$ & $5 \%$ & $9 \mathrm{~g}$ & $32 \%$ \\
\hline Potassium & $50 \mathrm{mg}$ & $0 \%$ & $50 \mathrm{mg}$ & $0 \%$ & $350 \mathrm{mg}$ & $6 \%$ & $690 \mathrm{mg}$ & $15 \%$ \\
\hline Sodium & $210 \mathrm{mg}$ & $9 \%$ & $250 \mathrm{mg}$ & $11 \%$ & $170 \mathrm{mg}$ & $7 \%$ & $25 \mathrm{mg}$ & $1 \%$ \\
\hline Protein & \multicolumn{2}{|l|}{$2 \mathrm{~g}$} & \multicolumn{2}{|l|}{$2 \mathrm{~g}$} & \multicolumn{2}{|l|}{$2 \mathrm{~g}$} & \multicolumn{2}{|l|}{$9 \mathrm{~g}$} \\
\hline Sugars & \multicolumn{2}{|l|}{$1 \mathrm{~g}$} & \multicolumn{2}{|l|}{$<1 \mathrm{~g}$} & \multicolumn{2}{|l|}{$<1 \mathrm{~g}$} & \multicolumn{2}{|l|}{$2 \mathrm{~g}$} \\
\hline
\end{tabular}

${ }^{\mathrm{a} D a t a}$ stated per FDA rounding regulations. Here, $\mathrm{g}$ - grams and $\mathrm{mg}$ - milligrams. Mushroom protein crisp is a baked product, and no fat was used in the process 


\section{Results}

\section{Market analysis}

The global salty sack market has been steadily growing in the past 5 years and is projected to keep growing in the next 5-years (Fig. 1a). There are a wide variety of snacks sold worldwide using agricultural produce and can be grouped in to 5-major categories and their market value are given in the bracket. Namely, (i) nonextruded (\$61.1 B), (ii) extruded (\$48.3 B), (iii) nuts (\$27 B), (iv) minimally processed (\$4.7 B) and (v) vegetable/ fruit snack (\$0.5B) (Fig. 1b). Among the snack categories the vegetable/fruit snack are becoming very popular among the public primarily due to health concerns and has seen a double-digit CAGR, while all other categories show only single digit growth. Majority of the mushroom snacks are sold in southeast Asian countries. In the North America market, very few of the snacks are mushroom based and the most noticeable product is fried button mushrooms. Other noticeable products including natural oyster mushroom chips and king oyster mushroom chips without seasoning are sold by $\mathrm{Wu}$ Feng Farmers' Association. Market analysis of healthy snack has shown that young adults are the biggest consumers of chips and snacks since they are more likely to try new flavors and brands. Also, younger consumers, vegetarian, and vegans, are expected to show more interest in high protein containing snacks. As a rule, consumer with a higher level of education have been exposed to and are more open to different types of healthy snack. Snacks with lower salt, fat and health benefits could appeal to older customers; particularly, to people with underlying health conditions like diabetes (Greener 2019), high blood pressure and heart conditions.

\section{Method of producing MPC}

Different processing steps and quality control and sensory tests were carried out to produce MPC as depicted in Fig. 2. Fresh king oyster mushrooms were purchased from local grocery store in East Lansing, MI, then they were cleaned, sliced using a vegetable slicer and baked in an oven with and without different seasoning to produce MPC. The mushroom slice thickness, baking time and amount of seasoning were varied. Thinner slice gave crispy texture. However, too thin slice crumbled during handling. Too thick slices had soft texture. The quality of MPC was initially screened by its appearance, crispy texture, and taste. To increase the protein content of mushroom crisp, commercially available proteins from vegetable source (e.g., soy, pea, and rice) and animal source (e.g., white of egg, milk) were purchased from a local health store and mixed along with seasoning in different amount (1-5\%). Adding different commercial proteins along with seasoning did change the flavor profile and texture of MPC when compared to control MPC without external protein addition (unreported results). Then, we evaluated different hydrolyzed peptides and found that adding hydrolyzed collagen (1-5\% based on dry weight of mushroom) did not change the flavor of the original MPC. Large quantity of MPC was produced without seasoning and sent for composition analysis at Great Lakes Scientific Inc., scientific lab in Michigan using standard AOAC protocols.

\section{Composition analysis of MPC}

About $750 \mathrm{~g}$ of MPC was freshly baked without any seasoning and sent for composition analysis. The standard deviation was found to be $<8 \%$ for vitamins and dietary fibers and $<5 \%$ for other components. The results showed that they contain $58.6 \%$ carbohydrates, $30.3 \%$ protein, $1.3 \%$ fat, $4.4 \%$ water, and $5.4 \%$ of others. About $53 \%$ of total carbohydrate in MPC was found to be soluble and insoluble dietary fiber comprising complex carbohydrates. About $10 \%$ of the carbohydrate is comprised of free sugars such as trehalose and mannitol as reported before. Other polysaccharides in MPC include chitin, $\alpha$ and $\beta$-glucans, and other hemicelluloses (e.g., mannans, xylans, and galactans). The $\beta$-glucans and some linear $(1 \rightarrow 3)$ - $\alpha$ - glucans in Pleurotus $s p$. contains unique glucan polysaccharide called pleuran, which is reported to have antitumor properties. MPC contain $0.1 \%$ of starch and no cholesterol, and it also contains essential Vitamins A, B1(thiamin), B2(riboflavin), B3(niacin), B6, B9 (folate), D and $\mathrm{E}$ as shown in Table 1. MPC also contain flavor compounds, essential minerals such as magnesium, selenium, copper, phosphorus, potassium, iron, and calcium. Previous studies have reported that king oyster mushroom contains all 20 essential and nonessential amino acids, Vitamin B12 (cobalamin), Vitamin $\mathrm{C}$ (ascorbic acid) and essential minerals such as zinc and manganese. However, these components and minerals were not quantified in this study.

\section{Sensory evaluation results}

A total of 80 consumers ranging in age from 18 to 65 (mean \pm standard deviation $[\mathrm{SD}]=33.5 \pm 11.9$ ) participated in the consumer liking test. The panelist who participated in this study were never trained on sensory evaluation before. The majority were female (77.5\%) and $83.8 \%$ completed 4-year college or graduate school (Table 2). The panelist annual income was between $\$ 15,000$ to $\$ 95,000$. Ninety percent of the participants reported that they consume chips (potato chips, vegetable chips, corn/tortilla chips) more than 3-4 times per month and $97.5 \%$ reported that they consume vegetables (sweet potatoes, carrots, mushrooms, squash, green beans, potatoes, beans, peas, or beets) more than 3-4 times per month. Only consumers who like mushroom, indicating 


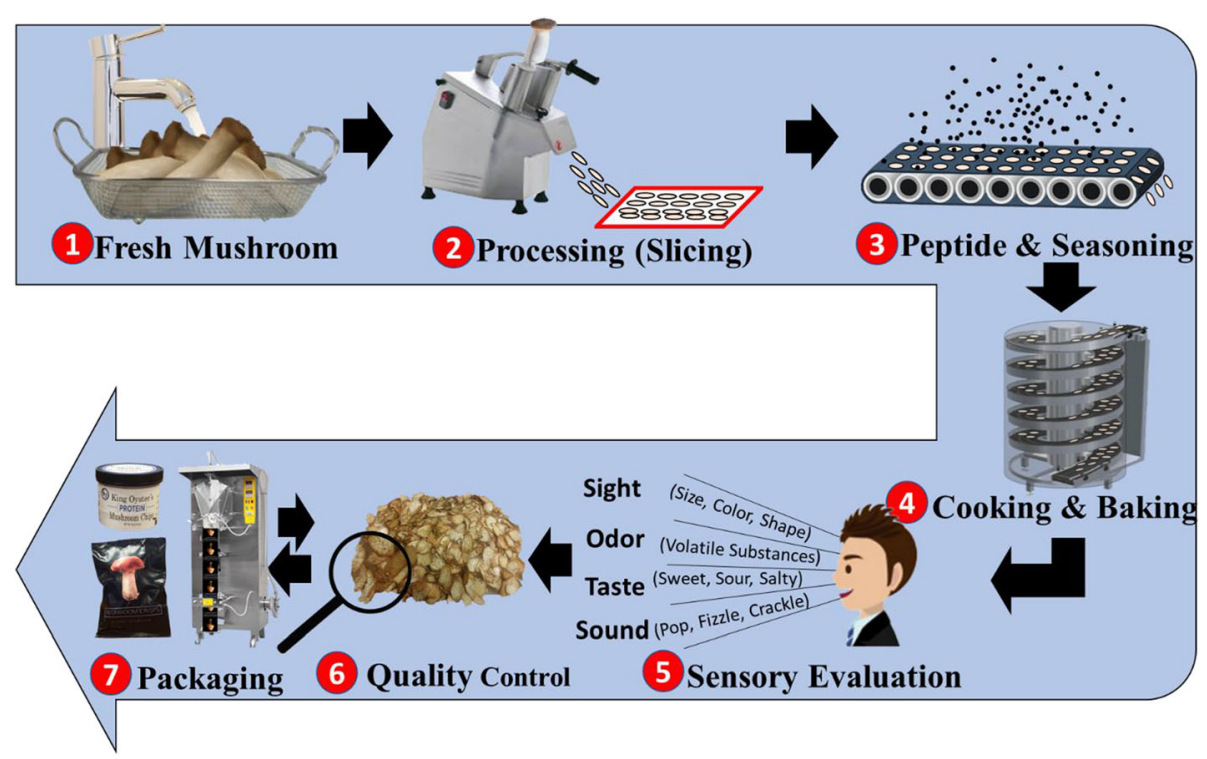

Fig. 2 Different steps involved in in producing quality MPC. Here, 1, Cleaning mushrooms with running water and wait until water drains out; 2 , Slicing mushrooms using vegetable processing machine; 3, Seasoning the slices; 4, baking using spiral oven; 5, Sensory evaluation using professional taste tester; 6 , quality control to remove deformed crisps and 7, packing using machine

more than 7 on a 9-point hedonic scale $(1=$ dislike extremely to $9=$ like extremely) took part in this testing.

Table 4 summarizes the sensory evaluation results based on four criteria, namely (i) flavor, (ii) appearance, (iii) texture and (iv) overall likings of control, garliconion, sugar- cinnamon flavored MPC. The average of these four criteria shows that seasoning did elevate the liking of MPC when compared to no seasoning which received a score of 5.1. Among the two seasonings, garlic, and onion MPC got a high score of 7.1 and cinnamon-sugar received 5.5. As shown in Table 4, control, garlic-onion, sugar-cinnamon flavored MPC significantly differed with respect to hedonic ratings of appearance, flavor, texture, and overall liking $(P<$ $0.0001)$; the participants significantly preferred the garlic -onion seasoned MPC with an overall liking score of 7.4 was preferred over the control (4.9) and sugar-cinnamon seasoned (5.1) MPC. Overall, sugar and cinnamon flavored MPC received higher liking scores of all sensory attributes, but there were no statistical differences except appearance liking.

Table 4 Appearance, flavor, texture, and overall liking ratings of mushroom chip samples

\begin{tabular}{|c|c|c|c|c|}
\hline & Appearance & Flavor & Texture & Overall Liking \\
\hline$(n=80)$ & $($ LS Mean \pm SD $)$ & & & \\
\hline Control & $5.3 \pm 1.9$ & $4.7 \pm 2.0$ & $5.5 \pm 2.1$ & $4.9 \pm 1.9$ \\
\hline Garlic onion & $6.3 \pm 1.7$ & $7.3 \pm 1.4$ & $7.3 \pm 1.4$ & $7.4 \pm 1.3$ \\
\hline Sugar cinnamon & $6.2 \pm 1.8$ & $4.8 \pm 2.2$ & $6.0 \pm 1.7$ & $5.1 \pm 2.1$ \\
\hline
\end{tabular}

Different letters in the same column show the significant differences between sample means at $p<0.05$ by Fisher's LSD
Figure 3 shows the values of the percentages obtained for attributes being "too little," "JAR," and "too much" for control, garlic-onion, sugar-cinnamon flavored MPC samples. Compared to the control, sugar-cinnamon flavored MPC samples, the garlic -onion flavored sample received higher percentages for the "Just About Right (JAR)" in all attributes. Sugar-cinnamon flavored MPC received higher JAR percentages in 'color' and 'crispness' attributes, but flavor-related attributes of sugarcinnamon flavored MPC such as 'overall flavor', 'seasoning flavor', and 'veggie flavor' were all significantly penalized $(P<0.05)$.

Nutritional facts of MPC versus other popular salty snacks When evaluating the nutritional facts of MPC, we found they contain only $100 \mathrm{cal}$ with one serving of $28 \mathrm{~g}$ when compared to other popular salty snacks that contain $150-160 \mathrm{cal}$ for the same serving (Table 3). Although, it is important to note, the serving size for the MPC provides more "chips" per serving weight of $28 \mathrm{~g}$, approximately 30 chips when compared to other brands around 12, 15 or 21. This volume could easily add to a higher level of snack satiety. The caloric content of the MPC is provided by carbohydrates and protein and void of fat. The latter macro nutrient is one that is most prominent in other salty snacks, and many are not able to reach a fat-free level. MPC also mostly contain complex carbohydrates, which are slower to digest when compared to higher starch content in most of the salty snacks. The dietary fiber content in MPC was found to be $32 \%$, which is 9-times higher when compared to other salty 


\section{$\because$ Too little $\square$ JAR $\square$ Too much}

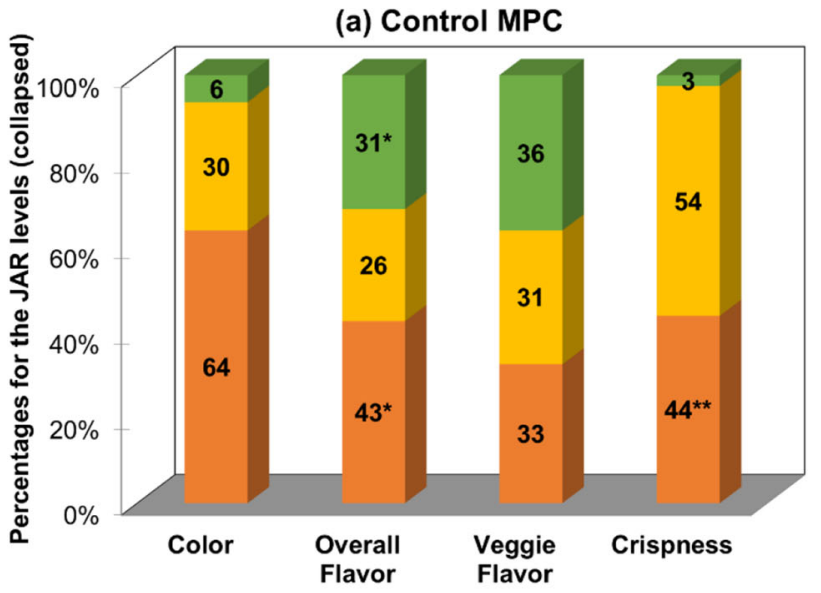

(b) Garlic onion MPC

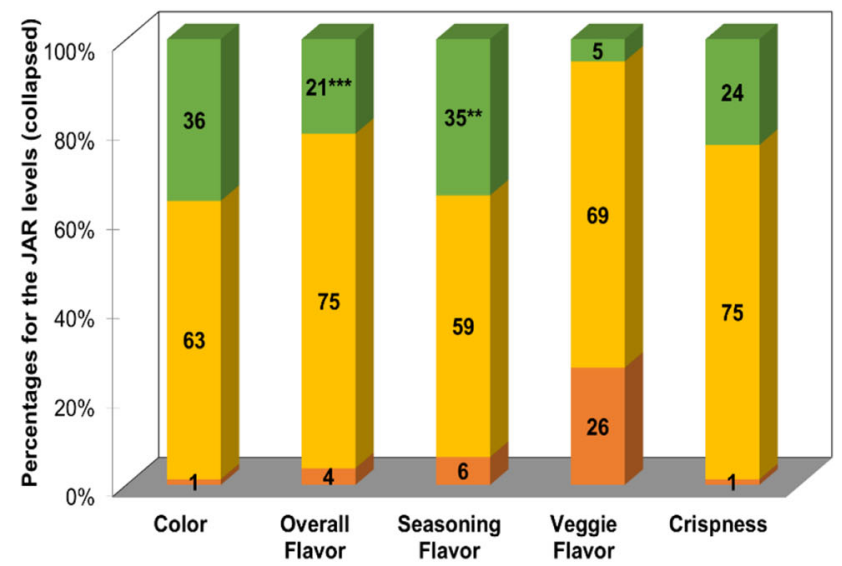

(c) Sugar cinnamon MPC

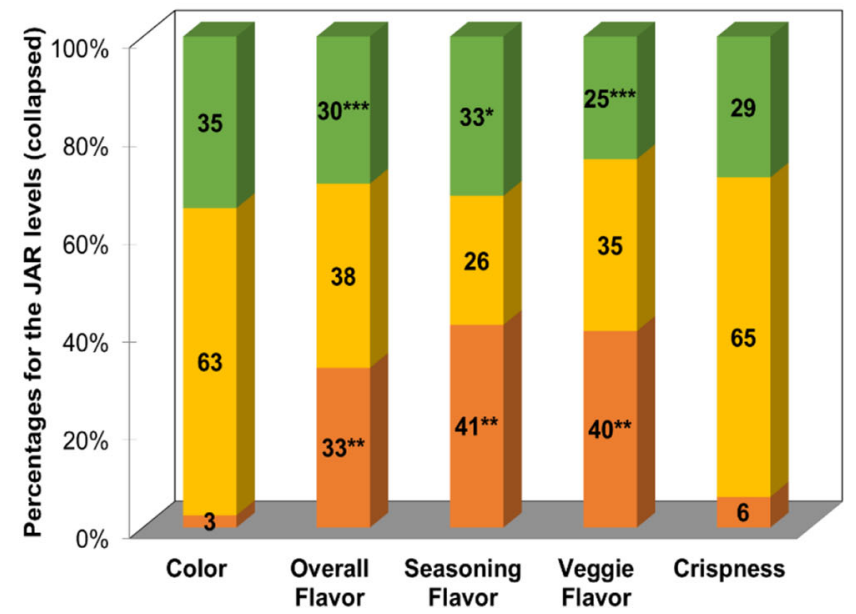

Fig. 3 Just-About-Right (JAR) scale percentages of responses grouped in three levels: Here, a Control, b Garlic onion, c Sugar cinnamon MPC ( $n=$ 80). Percentages with the star(s) attached represent significant penalties (drops in liking) due to the attributes being "too little" or "too much." * Indicates $P<0.05$; ${ }^{* *}$ indicates $P<0.01$; ${ }^{* *}$ indicates $P<0.0001$ 
snacks. The sodium content is 6- to 10-times less, while the potassium content ranged from $2 \mathrm{x}$ to $13 \mathrm{x}$ times higher and the protein content in MPC was four times higher when compared to popular snacks in the market. Health promoting nutraceuticals such as beta-glycan's (anticancer), homopolysaccharides (antiproliferative), lovastatin (hypolipidimic), lectins (cytoprotective and anti-viral), phenolic compounds (immunomodulatory, antimicrobial), di-terpenoids such as Eryngiolide A (antiinflammatory and cytotoxic), ergothioneine (antioxidant), and glycoproteins (hypoglycemic, neurogenic) are present in king oyster mushrooms should also be present in MPC. However, most of the above-mentioned nutritional components are either absent or present is lesser amount in salty snacks sold in the market. Also, unsaturated fatty acids such as oleic acid and linoleic acid are predominant in oyster mushrooms relative to saturated fatty acids. Overall, MPC is a nutritious snack with essential minerals, dietary fiber, protein, fat, and vitamins, which is beneficial for human well-being as summarized in Table S1.

\section{Packaging results and shelf life}

Table 5 summarizes the moisture content of the samples before and after 1,3 and 6 months of storage at $23^{\circ} \mathrm{C}$, $50 \% \mathrm{RH}$ and $37.8{ }^{\circ} \mathrm{C}, 85 \% \mathrm{RH}$. The \% moisture gained by the plain and garlic-onion seasoned samples was higher when they were stored at $37.8^{\circ} \mathrm{C}, 85 \% \mathrm{RH}$ than at $23^{\circ} \mathrm{C}$, $50 \% \mathrm{RH}(p<0.05)$ due to the higher driven force of water through the multilayer structure. However, no difference was found in percentage moisture gained between samples. When the mushroom samples were packed and sealed under $\mathrm{N}_{2}$, the $\mathrm{O}_{2}$ and $\mathrm{CO}_{2}$ contents were analyzed in the headspace before and after 1,3 , and 6 months of storage for the two samples at the two different conditions. After 6 months of storage, the levels of $\mathrm{CO}_{2}$ were below the detection level of the instrument $\left(<0.1 \% \mathrm{CO}_{2}\right)$. In the case of $\mathrm{O}_{2}$ content, the \% gained was the same regardless the type of sample and the condition $(p>0.05)$. Interestingly, samples stored at $37.8{ }^{\circ} \mathrm{C}$ and $85 \% \mathrm{RH}$ showed a decline of $\mathrm{O}_{2}$ concentration inside the multilayer bags, which may be attributed to $\mathrm{O}_{2}$ consumption by an oxidation reaction in the samples after 3 months at this storage conditions. However, no difference between the samples were detected during sensory evaluation.

\section{Chemical analysis of MPC}

Acetone extracts of MPC were analyzed by Agilent GCMS to evaluate whether processing led to formation of flavor compounds with potentially undesirable aroma and flavor characteristics. The majority of MPC products showed no detectable volatile substances other than substances also found in the acetone solvent blank (traces of acetic acid and acetone condensation products). A lemon pepper-flavored MPC showed the greatest variety of compounds including monoterpenes carene, limonene, and p-cymene, caryophyllene, and piperonal, the latter being an expected constituent of black pepper. None of the MPC samples contained detectable levels of pyrazines, imidazole's, acetamide, or known pesticides. The findings suggest that under the conditions used for processing in this study, generation of Maillard products such as pyrazines was minimal to none (Figure S3).

\section{Discussion}

Tuber vegetables (grown under the ground) such as potato, sweet potato, turnips, yucca/cassava are conventionally sliced, fried/baked to produce chips, then seasoned, packed, and then sold in the market. However, most of the chips contain starch and easily digested when consumed and converted to glucose. Consuming the chips beyond the recommended portion size increases the calorie intake with excess sugar being then converted into fat and this is one of the leading causes of obesity (Muraki et al. 2016). Patients with diabetic conditions should avoid these starch rich snacks as they will experience sugar spike in their blood stream that

Table 5 Moisture and oxygen content in \% for Mushroom Protein Crisp after 1, 3, and 6 months of storage

\begin{tabular}{llllllll}
\hline & Condition & Sample & 0 month & 1 month & 3 months & $\mathbf{6}$ months & Gain in grams between $\mathbf{0}$ and $\mathbf{6}$ months \\
\hline Moisture, \% & $23^{\circ} \mathrm{C}, 50 \% \mathrm{RH}$ & Plain & $4.22 \pm 0.48$ & $4.46 \pm 0.19$ & $4.09 \pm 0.11$ & $5.28 \pm 0.00$ & $1.06 \pm 0.48$ \\
& & Garlic-onion & $4.74 \pm 0.88$ & $5.20 \pm 0.19$ & $4.99 \pm 0.18$ & $6.16 \pm 0.12$ & $1.41 \pm 0.76$ \\
& \multirow{2}{*}{$37.8^{\circ} \mathrm{C}, 85 \% \mathrm{RH}$} & Plain & $4.22 \pm 0.48$ & $5.99 \pm 0.20$ & $8.30 \pm 0.23$ & $11.78 \pm 0.10$ & $7.56 \pm 0.38$ \\
& & Garlic-onion & $4.74 \pm 0.88$ & $6.54 \pm 0.06$ & $8.60 \pm 0.35$ & $12.52 \pm 0.00$ & $7.78 \pm 0.88$ \\
Oxygen, \% & \multirow{2}{*}{$23^{\circ} \mathrm{C}, 50 \% \mathrm{RH}$} & Plain & $0.06 \pm 0.01$ & $16.55 \pm 2.90$ & $20.60 \pm 0.42$ & $20.9 \pm 0.00$ & $20.84 \pm 0.01$ \\
& & Garlic-onion & $0.13 \pm 0.13$ & $17.75 \pm 3.04$ & $20.60 \pm 0.42$ & $20.9 \pm 0.00$ & $20.77 \pm 0.13$ \\
& \multirow{2}{*}{$37.8^{\circ} \mathrm{C}, 85 \% \mathrm{RH}$} & Plain & $0.05 \pm 0.01$ & $18.05 \pm 3.18$ & $19.75 \pm 0.49$ & $15.40 \pm 4.81$ & $15.35 \pm 4.82$ \\
& & Garlic-onion & $0.03 \pm 0.01$ & $19.05 \pm 1.91$ & $19.80 \pm 0.42$ & $15.45 \pm 3.89$ & $15.42 \pm 3.88$ \\
\hline
\end{tabular}

Values with the same capital letter within plain and garlic-onion samples at the same treatment conditions are not different ( $a=0.05)$. Values with the same lowercase within the same sample and different treatment conditions (i.e., $23^{\circ} \mathrm{C}, 50 \% \mathrm{RH}$ and $\left.37.8{ }^{\circ} \mathrm{C}, 85 \%\right)$ are not different $(\mathrm{a}=0.05)$. The $\mathrm{CO}{ }_{2} \mathrm{Concentration}$ in the head space was found to be below detection limit during the entire storage experiment 
will lead to other complications (Synytsya et al. 2009). An alternative option is to produce a snack using mushrooms that are known to contain complex carbohydrates, dietary fiber, essential minerals, protein, unsaturated fats, several vitamins, and minerals and, nutraceutical compounds (Fig. 4). Additionally, king oyster mushroom do not contain starch (Zheng et al. 2017). Mushrooms are either freeze dried, puffed by subjecting to high temperature and pressure or fried, seasoned, and sold (Li et al. 2018; Tu et al. 2020). In some cases, dried mushroom powers are mixed with starch in different ratios and processed to make snack (Liu et al. 2018). However, these so-called mushroom snacks contain sizable amount of starch.

To produce mushroom chips like the one made from tuber vegetables, one needs hard tuber shaped mushrooms or mushroom stems. Several mushroom varieties were taken into consideration and MPC was produced using milky white (Calocybe indica), puff ball (Calvatia gigantea), king oyster (Pleurotus eryngii) and button (Agaricus bisporus). Among the different varieties that were used to produce MPC in baking oven, king oyster mushrooms gave crispy texture, and its appearance was like yucca/turnip chips and had sweet, umami flavor when consumed without seasoning. We optimized MPC processing conditions by varying the thickness of mushroom slices, baking temperature and time, different seasoning type, their amount and when to add the seasoning. Subsequently, the MPC without seasoning was sent for composition analysis and found to contain all the components which the fresh king oyster mushroom was known to have (Garnier et al. 2010).

Sensory evaluation revealed that participants liked MPC with garlic-onion seasoning significantly more than those with sugar-cinnamon or with no seasoning (control). JAR ratings also indicate that the garlic-onion seasoning improved not only flavor but also appearance (color) and texture (crispness), compared with control (plain) MPC. This indicates the addition of a certain type of seasoning to MPC would increase the likability of MPC. Furthermore, JAR ratings found that all the flavor-related attributes (overall, seasoning, veggie flavor) of sugar-cinnamon flavored MPC did not meet consumer expectations or preferences. Interestingly, these flavor-related attributes were judged as "too little" and also "too much" by more than $25 \%$ of participants, and these were all significantly penalized $(P<0.05)$, resulting in drops in the overall liking score. This might be since

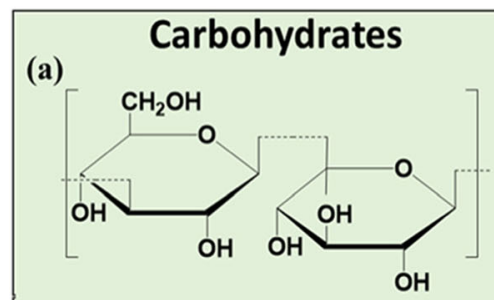

(b)

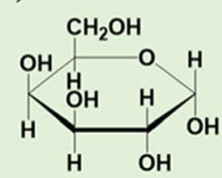

(c)

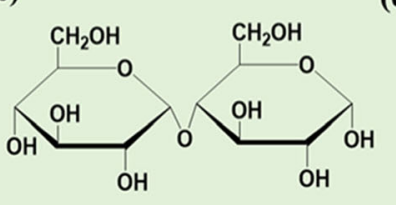

(g)

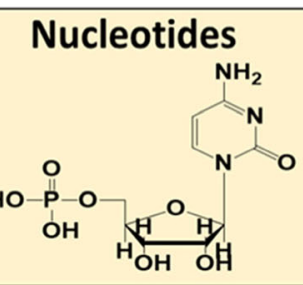

(h)

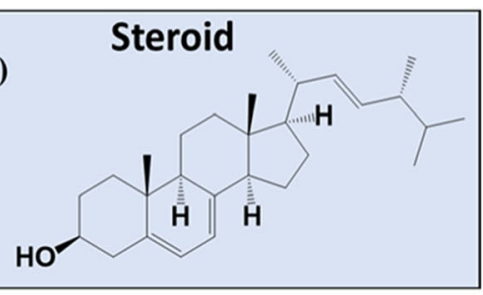

(d)

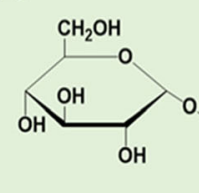

(e)

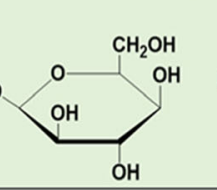

(f)

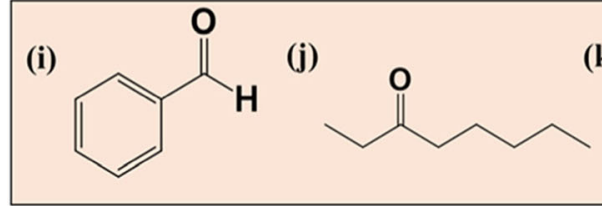

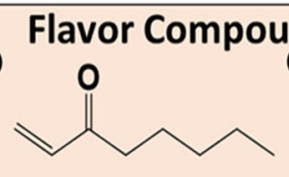

(I)

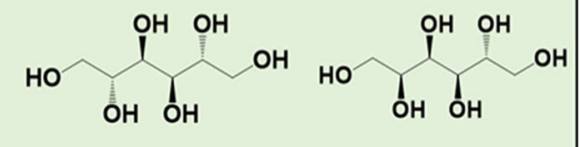

(n)<smiles>N#[14C]C(=O)OC(=O)O</smiles>

(o)

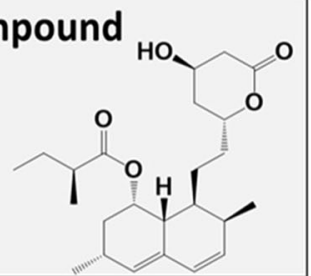

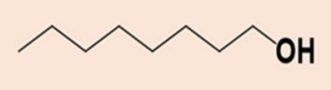

(m)

Fig. 4 Some of the major health promoting component present in king oyster mushrooms. Here, a Pleuran - an insoluble polysaccharide ( $\beta$-(1,3/ 1,6)-D-glucan); b galactose; c Maltose; d Tréhalose; e Manitol; f Sorbitol; g 5'-CMP, 5'-cytosine monophosphate, h Ergosterol; i Benzaldéhyde; j 3Octanone; k 1-Octen-3-one; I 1-Octanol; m 2-Octen-1-ol; $\mathbf{n}$ Tartaric acid; o Lovastatin; $\mathbf{p}$ Ergothioneine and $\mathbf{q}$ Arginine 
addition of sugar-cinnamon seasoning was not evenly distributed and thus, some received MPC with little sugar-cinnamon seasoning and others received MPC with too much seasoning. Sugar-cinnamon seasoned MPC may be more acceptable with respect to flavor by adding the right amount of seasoning.

Packaging snacks such as MCP requires optimal protection against water and oxygen permeation to secure a long shelf life without nutritional and flavor alterations. We studied a multilayer metalized bag with potential barrier properties for MCP protection. An average water rate increases of around 5 and $30 \%$ was determined on samples at $23^{\circ} \mathrm{C}, 50 \% \mathrm{RH}$, and $37.8^{\circ} \mathrm{C}, 85 \% \mathrm{RH}$, respectively. Storage at higher temperatures and humidity (i.e., $37.8^{\circ} \mathrm{C}, 85 \%$ $\mathrm{RH})$ are intended to simulate longer storage time in actual retail conditions. In the case of oxygen permeation, a rapid increase was observed in all the samples reaching almost the same external conditions by 3 months of storage. Fast ingress of $\mathrm{O}_{2}$ through metalized layer structures can be attributed to small pinholes or defects on the aluminum layer, causing a channeling effect on the barrier structure and deteriorating the barrier of the system (Baer et al. 1997). So, commercialization of the MCP will require a multilayer bag with better water and oxygen barrier properties to guarantee long term shelf life. Further studies are necessary to develop an optimal packaging solution fully.

The MPC nutritional profile provides a nutrient dense and well-balanced snack option with a very moderate calorie content. For $100 \mathrm{cal}$, the MPC provides the protein comparable to $1 \mathrm{oz}$ of meat/cheese with complex carbohydrates for snack satiety and slower digestion, with the aid of a high DF content. Even though the MPC are fat-free on an FDA serving size, the $1.3 \mathrm{~g}$ of fat provided on a $100 \mathrm{~g}$ serving, provides a healthy fat component with primarily being unsaturated fats and nearly void of saturated fat. Other critical nutrient contributions include its lack of high sodium content and generous potassium content, when compared to other salty snack options (Table 3), MPC are also more vitamin and mineral dense due its vegetable base of mushrooms, unlike snacks (chips) made from potato or corn. Refer to Table 1 for an outline of those specific vitamin/minerals.

Another important highlight of the MPC is that it contains $32 \%$ dietary fiber and $30 \%$ protein, which is $9 \mathrm{x}$ and $4 \mathrm{x}$ times higher when compared to other snacks sold in the market, respectively. Taking more DF also reduces energy absorption by the means of diluting consumed food energy availability (Anderson 2008). The DF's have also been reported to increase response of gastrointestinal hormones that stimulate insulin release and affect appetite (Manikkam et al. 2016).

The health benefits of Adenosine 5' monophosphate could be amplified using hydrolyzed proteins produced using microbial fermentation of proteins or using enzyme called protease such as pepsin, trypsin, chymotrypsin, and elastase to peptides (Skov et al. 1999). Most of the protein was extracted from cereal grains (e.g., rice, oat, soy, and corn), nuts (e.g., peanut and almond), vegetables (e.g., green peas and chickpeas), algal protein and animal products (e.g., fish, beef) and further process to produce peptides. Adding hydrolyzed proteins to MPC while processing is expected to help maintain a lean body mass and an increase protein intake is associated with a voluntary reduction in food intake (Alonso-Galicia and Magdalena 1996) and provide physiological/systemic health benefits. The mechanism by which these bioactive peptides control hypertension and maintain lean body mass is by targeting the renin-angiotensin system (hormone system that regulates blood pressure, fluid, and electrolyte balance) by inhibiting the activity of angiotensin-converting enzyme and preventing the formation of angiotensin II (Admassu et al. 2017; Bennet et al. 2009). This is important because angiotensin II is a peptide hormone that increases blood pressure by stimulating the G-proteins in the vascular smooth muscle cells, and increases blood volume, pressure, and $\mathrm{pH}$ by acting on the $\mathrm{Na}+/ \mathrm{H}+$ exchanger in the kidney. Satiety is achieved through the production of amino acids (AA), which can be linked via the vagal (or vagus) nerve, to the brain's sense of hunger (Shimizu 2012). Bioactive peptides like Calpis ${ }^{\circ}$ (Japan), Evolus ${ }^{\bullet}$ (Finland), Collactive $^{\text {Tx }}$ and Nutripeptin ${ }^{\text {Tx }}$ (France) are commercial products with Food for Specified Health Use (FOSHU) claims (Stea et al. 2014).

Adolescence is a vital time in human life span, as it is a period where the body changes, affecting the nutritional and dietary needs of the child. It is during this time as well that teens increase their snacking rate, either during or after school, which also increases their irregular eating habits. This is a huge concern because children who engage in irregular eating/snacking are at a greater risk for being overweight and/or obese (Drzikova et al. 2007). Beta-glucans gain their effects from their structure of their side chains, which are specific to individual fungal species. It has been seen that the biological activities of the water-soluble form of beta-glucans have a greater effect in humans, especially on the immune systems. Though the underlying principles of how betaglucans affect the immune system are not fully known, it has been observed that they interact with specific betaglucopyranose receptors on leukocytes, which can increase the counteracting activity of these cells against foreign substances or diseases, which can include cancer.

Cholesterol is a huge issue that has a source from unhealthy choices in snacks. There have also been studies; both in-vitro and in-vivo, on animals have shown that beta-glucan rich diet can reduce serum 
cholesterol and lipoprotein concentration due to the excretion of bile acids (Handayani and Chen 2011; Rop et al. 2009). MPC for that matter, have a betaglucan, Pleuran, that can help combat this condition, as seen in experiments done in the blood of hamsters and rats (Braaten et al. 1994). Fungal beta-glucans also reduced the levels of both the overall levels of cholesterol and of LDL cholesterol ("bad" cholesterol), while also slightly increasing the levels of HDL cholesterol ("good" cholesterol) (Bianchini et al. 2002). Correlating to eating habits, unhealthy choices in foods, just like our focus in snacking, can lead to conditions like obesity, which can then lead to more serious conditions, such as cancer. Eating these fast foods, filled with fats and sugars, are not as easily processed in our bodies, and aid in the gaining of weight, with strong evidence that being overweight can cause one or more of 12 types of cancer (Sung et al. 2019). Starting from eating right, MPC do not aid in cancer forming cells, and their main points include mitigating gain weight in humans.

\section{Conclusions}

We optimized the method of producing MPC and received a 7.1 average score in a nine-point hedonic scale from 80 people who participated in sensory evaluation analysis. Type of seasoning and quantity of seasoning plays an important role in increasing the likability of MPC. The composition of MPC shows that it is packed with essential vitamins, beta-glucans, antioxidants, essential minerals, unsaturated fats, and nutraceuticals that promote physiological and systemic human health. The MPC has healthy ingredients and satisfy all the features of GHS. It contains $32 \%$ dietary fiber, $30 \%$ protein with no starch and has potential to benefit people with medical conditions such as obesity and diabetes, children, and sports personnel. The MPC did not contain any Millard reaction products such as imidazole's and pyrazines confirmed by GC-MS due to mild processing conditions. MPC also contain at a minimum $30-35 \%$ fewer calories when compared to commercially popular snacks sold in the market. A six-month storage experiment has shown that the samples are shelf stable. Supplementing hydrolyzed peptides along with seasoning whole processing MPC did not change its appearance and sensory characteristic but elevates the physiological and systemic health benefits for consumers. Overall, our study suggests that MPC will be a healthy alternative to salty starch rich snacks and benefit diverse population.

\section{Abbreviations}

MPC: Mushroom protein crisp; CAGR: Compound annual growth rate; DF: Dietary fiber; USDA: United States Department of Agriculture; GHS: Good healthy snack; AOAC: Association of official agricultural chemists;
MSU: Michigan State University; UH: University of Houston; HPLC: High performance liquid chromatography; GC-MS: Gas chromatography followed by mass spectrometry analysis; RH: Relative humidity; FDA: Federal drug administration; SD: Standard deviations; JAR: Just about right

\section{Supplementary Information}

The online version contains supplementary material available at https://doi. org/10.1186/s43014-021-00077-7.

\begin{abstract}
Additional file 1: Figure S1. A) Buckets with magnesium nitrate saturated salt solution for storage conditions at $23^{\circ} \mathrm{C}, 50 \%$, and B) Bags inside the chamber for storage conditions at $37.8{ }^{\circ} \mathrm{C}, 85 \% \mathrm{RH}$. Figure $\mathbf{S 2}$. Plain and garlic-onion mushrooms chips packed in metallized bags. Figure S3. GC-MS chromatogram of acetone extract of lemon pepperflavored MPC showing monoterpene and sesquiterpene flavor compounds, piperonal and other unidentified aromatic compounds, and a 2,5-furandione derivative believed derived from an organic acid. Peaks highlighted with $\left(^{*}\right)$ are solvent impurities present in acetone blank analyses. Anticipated Maillard products such as pyrazines were below the limits of detection. Table S1. Comparison of main attributes of MPC to other popular salty snacks.
\end{abstract}

\section{Acknowledgements}

We thank Studer-Rabeler, Karen for her support and motivation for completing this project. We also thank undergraduate student Ms. Jacqueline Calzada from University of Houston who provided support in preparing this manuscript. We are grateful to Dr. Scott Smith of the Michigan State University Mass Spectrometry and Metabolomics Core for performing GC-MS analyses.

\section{Authors' contributions}

Venkatesh Balan: Came with original idea, designed, and carried out most of the experiments, contributed to manuscript writing; Dianne Novak: Evaluated the nutrition of MPC and contributed manuscript writing and editing; William Knudson: Carried out market analysis, A. Daniel Jones: Carried out GC-MS analysis, contributed to manuscript editing; Fabiola Maria IñiguezFrancod: Carried out packaging analysis; Rafael Auras: Designed the packaging experiments and contributed to manuscript writing; Sungeun Choe: performed sensory evaluation and contributed to manuscript writing; Amanda Rodgers and Bryan Ubanwa: Helped drafting the figures and tables, contributed to literature survey. The author(s) read and approved the final manuscript.

\section{Funding}

The research was supported by the Michigan Translational Research and Commercialization (MTRAC) Innovation Hub for AgBio, co-funded by the Michigan Economic Development Corporation (MEDC) through the Michigan Strategic Fund. VB thank the University of Houston for providing synergy grant and state of Texas for startup funds. ADJ acknowledges support from Michigan AgBioResearch through the USDA National Institute of Food and Agriculture, Hatch project number MICL02474 and Engineering for agriculture production system project number G0505650.

\section{Availability of data and materials}

Not applicable.

\section{Declarations}

Ethics approval and consent to participate

Sensory evaluation was done with approval from MSU IRB and with the consent of the participants.

Consent for publication

Not applicable.

Competing interests

The authors declare no conflict of interest. 


\section{Author details}

${ }^{1}$ Department of Engineering Technology, Biotechnology Program, College of Technology, University of Houston, TX 77479 Sugar Land, USA. ${ }^{2}$ Product Center, Michigan State University, East Lansing, MI 48824, USA. ${ }^{3}$ Department of Biochemistry and Molecular Biology, Michigan State University, East Lansing, MI 48824, USA. ${ }^{4}$ School of Packaging, College of Agriculture \& Natural Resources, Michigan State University, East Lansing, Ml 48824, USA.

${ }^{5}$ Department of Poultry Science, Auburn University, Auburn, AL 36849, USA.

Received: 4 April 2021 Accepted: 21 September 2021

\section{Published online: 01 December 2021}

\section{References}

Admassu, H., Gasmalla, M. A. A., Yang, R., \& Zhao, W. (2017). Bioactive peptides derived from seaweed protein and their health benefits: Antihypertensive, antioxidant, and antidiabetic properties. Journal of Food Science, 83(1), 6-16. https://doi.org/10.1111/1750-3841.14011.

Aghayan, M., Asghari, G., Yuzbashian, E., Dehghan, P., Haghighian, H. K., Mirmiran, P., \& Javadi, M. (2019). Association of nuts and unhealthy snacks with subclinical atherosclerosis among children and adolescents with overweight and obesity. Nutrition and Metabolism, 16(1), 23. https://doi.org/10.1186/s12 986-019-0350-y.

Agrahar-Murugkar, D., Zaidi, A., \& Dwivedi, S. (2018). Quality of nixtamalized, sprouted and baked multigrain chips. Nutrition and Food Science, 48(3), 453467. https://doi.org/10.1108/NFS-11-2017-0252.

Alonso-Galicia, M., \& Magdalena, A. G. (1996). Hypertension in obese zucker rats. Role of angiotensin II and adrenergic activity. Hypertension, 28(6), 1047-1054. https://doi.org/10.1161/01.HYP.28.6.1047.

Analyst (1985). Determination of vitamin a in animal feeding stuffs by highperformance liquid chromatography. Analytical Methods Committee, 110, 1019-1026.

Anderson, J. W. (2008). Dietary fiber and associated phytochemicals in prevention and reversal of diabetes. Nutraceuticals, glycemic health and type 2 diabetes, chapter 7. Book Editor(s): Pasupuleti, V. K., Anderson, J.W. https://doi.org/10.1 002/9780813804149.ch7.

Baer, A. J., Rumpler, W. V., Miles, C. W., \& Fahey Jr., G. C. (1997). Dietary fiber decreases the metabolizable energy content and nutrient digestibility of mixed diets fed to humans. The Journal of Nutrition, 127(4), 579-586. https:// doi.org/10.1093/jn/127.4.579.

Bennet, J., Rhodes, M., Malcolm, P., Dainty, J., Simpson, B., Johnson, I., ... Williams, S. (2009). Assessment of the relationship between post-meal satiety, gastric volume, and gastric emptying after swedish adjustable gastric banding. A pilot study using magnetic resonance imaging to assess post-surgery gastric function. Obesity Surgery, 19(6), 757-763. https://doi.org/10.1007/s11695-0089596-6.

Bianchini, F., Kaaks, R., \& Vainio, H. (2002). Overweight, obesity, and cancer risk. The Lancet Oncology, 3(9), 565-574. https://doi.org/10.1016/S1470-2045(02 )00849-5.

Bingqiang, Y. (2015). Mushroom potato chips and preparation method there-of. CN103300321B

Braaten, J., Wood, P., Scott, F., Wolynetz, M., Lowe, M., Bradley-Whtie, P., \& Collins, M. (1994). Oat beta-glucan reduces blood cholesterol concentration in hypercholesterolemic subjects. European Journal of Clinical Nutrition, 48(7), 465-474.

Businesswire (2020). Global savory snacks sector estimated to be valued at us $\$ 176.8$ billion by 2023 with a CAGR of 5.2\%. Research and Markets. https:// www.businesswire.com/news/home/20200206005462/en/Global-Savory-Sna cks-Sector-Estimated-to-be-Valued-at-US-176.8-Billion-by-2023-with-a-CAGRof-5.2---ResearchAndMarkets.com.

Carrasco-González, J. A., Serna-Saldívar, S. O., \& Gutiérrez-Uribe, J. A. (2017). Nutritional composition, and nutraceutical properties of the Pleurotus fruiting bodies: Potential use as food ingredient. Journal of Food and Compositional Analysis, 58, 69-81. https://doi.org/10.1016/j.jfca.2017.01.016.

Chao, L., Yong, L., Xuebing, S., Zhonghua, G., Jui, S., Jie, Q., ... Ningping, Q. (2013) Reshaped pleurotus eryngii and grape skin compound crisp chip and method for making same. CN102894350B.

Chatterjee, P. (2016). Edible mushroom- a nutritious food improving human health. International Journal of Clinical and Biomedical Research, 2016(2), 34-37.

Chen, X., Yu, J., Cui, H., Xia, S., Zhang, X., \& Yang, B. (2018). Effect of temperature on flavor compounds and sensory characteristics of Maillard reaction products derived from mushroom hydrolysate. Molecules, 23(2), 247. https:// doi.org/10.3390/molecules23020247.

Cho, K. Y., \& Risvi, S. S. (2010). New generation of healthy snack food by supercritical fluid extrusion. Journal of Food Processing and Preservation, 34(2), 192-218. https://doi.org/10.1111/j.1745-4549.2009.00372.x.

Chune, H. (2013). Vacuum freeze-dried Pleurotus eryngii crisp chip and preparation method thereof. CN103039957A.

CSP daily news (2016). Snacks: salty snack 2016. CSP Daily News https://www. cspdailynews.com/category-management-handbook/snacks-salty-snacks-201 6. Accessed 4.3.2021.

Drzikova, A., Dongowski, G., \& Gebhardt, E. (2007). Dietary fiber-rich oat-based products affect serum lipids, microbiota, formation of short-chain fatty acids and steroids in rats. British Journal of Nutrition, 94(6), 1012-1025. https://doi. org/10.1079/BJN20051577.

Garnier, G., Yrieix, B., Brechet, Y., \& Flandin, L. (2010). Influence of structural feature of aluminum coatings on mechanical and water barrier properties of metallized PET films. Journal of Applied Polymer Science, 115(5), 3110-3119. https://doi.org/10.1002/app.31372.

Ghosh, K. (2016). A review: Edible mushrooms as source of dietary fiber and its health effects. Journal of Physical Sciences, 21, 129-137.

Greener, M. (2019). As cheap as chips: Obesity and early-onset type 2 diabetes. Practical Diabetes, 36(1), 26-29. https://doi.org/10.1002/pdi.2207.

Gupta, S., Summuna, B., Gupta, M., \& Annepu, S. K. (2018). Edible mushrooms: Cultivation, bioactive molecules, and health benefits. Bioactive Molecules in Food, 1, 1-33. https://doi.org/10.1007/978-3-319-54528-8_86-1.

Handayani, A., \& Chen, J. (2011). Dietary shiitake mushroom (Lentinus edodes) prevents fat deposition and lowers triglyceride in rats fed a high- fat diet. Journal of Obesity. 2011:258051.

Hengsheng, S., Pufu, L., Junchen, C., Yibin, L., \& Li, W. (2013). Method for preparing non-fried edible-fungus crisp chips through two-section water-removing and three-temperature-section drying. CN102599486B.

Hess, J. M., Jonnalagadda, S. S., \& Slavin, J. L. (2016). What is a snack, why do we snack, and how can we choose better snacks? A review of the definitions of snacking, motivations to snack, contributions to dietary intake, and recommendations for improvement. Advances in Nutrition an International Review Journal, 7(3), 466-475. https://doi.org/10.3945/an.115.009571.

Ilkay, J. (2013). Identifying motives of mothers who purchase healthy convenience snacks for their children: A phenomenological study. Journal of Business Studies Quarterly, 5(2), 237-246.

Lattimer, J. M., \& Haub, M. D. (2010). Effects of dietary fiber and its components on metabolic health. Nutrients, 2(12), 1266-1299. https://doi.org/10.3390/ nu2121266.

Li, T., Lee, J., Luo, L., Kim, J., \& Moon, B. (2018). Evaluation of the effects of different freezing and thawing methods on the quality preservation of Pleurotus eryngii. Applied Biological Chemistry, 61(3), 257-265. https://doi.org/1 0.1007/s13765-018-0354-8.

Li, Y. O., \& Komarek, A. R. (2017). Dietary fibre basics: Health, nutrition, analysis, and applications. Food Quality and Safety, 1(1), 47-59. https://doi.org/10.1093/ fqs/fyx007.

Liu, Y., Zheng, W., Ibrahim, S. A., Yang, H., \& Huang, W. (2018). Chemical properties of vacuum fried Pleurotus eryngii during storage and characterization of brown pigment. International Journal of Food Properties, 20, S2349-S2358.

Manikkam, V., Vasiljevic, T., Donkor, O. N., \& Mathai, M. L. (2016). A review of potential marine-derived hypotensive and anti-obesity peptides. Critical Reviews in Food Science and Nutrition, 56(1), 92-112. https://doi.org/10.1080/1 0408398.2012.753866.

Marshall, E., \& Nair, N. G. (2009). Make money by growing mushrooms. Food and agriculture organization of the United Nations (FAO). FAO Diversification Booklet 7. Rome, 1, 1-50.

Mattila, P., Salo-Väänänen, P., Könkö, K., Aro, H., \& Jalava, T. (2002). Basic composition and amino acid contents of mushrooms cultivated in Finland. Journal of Agricultural Food Chemistry, 50(22), 6419-6422. https://doi.org/10.1 021/jf020608m.

Muhammed, A., Sadik, J. A., Admasu, W., \& Satheesh, N. (2020). Optimization of lupine (Lupinus albus) composition, feed moisture content and barrel temperatures for best quality maize based extruded snack food. Nutrition and Food Science, 50(5), 853-869.

Murakami, K., \& Livingstone, M. B. E. (2016). Associations between meal and snack frequency and overweight and abdominal obesity in US children and adolescents from National Health and nutrition examination survey (NHAN 
ES) 2003-2012. British Journal of Nutrition, 115(10), 1819-1829. https://doi. org/10.1017/S0007114516000854.

Muraki, I., Rimm, E. B., Willett, W. C., Manson, J. E., Hu, F. B., \& Sun, Q. (2016). Potato consumption and risk of type 2 diabetes: Results from three prospective cohort studies. Diabetes Care, 39(3), 376-384. https://doi.org/1 $0.2337 / \mathrm{dc} 15-0547$.

Niekerk, P. J. V., \& Macrae, R. (1988). In HPLC in food analysis, $2^{\text {nd }}$ ed. Academic Press, 1, 144 ISBN-13: 978-0124647817; ISBN-10: 0124647812.

Ning, J., Xia, L., Dajing, L., \& Chunquan, L. (2012). Puffed pleurotus eryngii chip production process and puffed pleurotus eryngii chip products. CN101933617B.

Ouhtit, A., Al-Sharbati, M., Gupta, I., \& Al-Farsi, Y. (2014). Potato chips and childhood: What does the science say? An unrecognized threat? Nutrition, 30(10), 1110-1112. https://doi.org/10.1016/j.nut.2014.01.008.

Pérez-Gimeno, G., Rupérez, A. I., Vázquez-Cobela, R., Herráiz-Gastesi, G., GilCampos, M., Aguilera, C. M., ... Bueno-Lozano, G. (2020). Energy dense salty food consumption frequency is associated with diastolic hypertension in Spanish children. Nutrients, 12(4), 1027. https://doi.org/10.3390/nu12041027.

Poddar, K. H., Feeney, M. J., \& Cheskin, L. J. (2012). Edible mushrooms: Potential role in weight regulation. Mushrooms: Types, Properties and Nutrition, 1, 27-54.

Qinzhu, Z., Yan-ling, C., Dong-Xiao, S., Tian, B., Yang, Y., \& Shan, H. (2017). Process optimization and anti-oxidative activity of peanut meal Maillard reaction products. LWT Food Science and Technology, 97, 573-580. https://doi.org/10.1 016/j.Iwt.2018.07.025

Qiuhui, H., Fei, P., Min, W., Liyan, Z., Xinxin, A., Yong, F., ... Ning, M. (2014) Method for producing instant pleurotus eyringii chips. CN102028192B.

Rathore, H., Prasad, S., \& Sharma, S. (2017). Mushroom nutraceuticals for improved nutrition and better human health: A review. Pharma Nutrition, 5(2), 35-46. https://doi.org/10.1016/j.phanu.2017.02.001.

Ren, A., Chen, G., \& Li, W. (2010). Method for producing primary color low fat crisp mushroom chips. CN101919429A.

Rios-Hoyo, A., \& Gutierrez-Salmean, G. (2016). New dietary supplements for obesity: What we currently know. Current Obesity Reports, 5(2), 262-270. https://doi.org/10.1007/s13679-016-0214-y.

Roncero-Ramos, I., \& Delgado-Andrade, C. (2017). The beneficial role of edible mushrooms in human health. Current Opinion in Food Science, 14, 122-128. https://doi.org/10.1016/j.cofs.2017.04.002.

Rop, O., Mlcek, J., \& Jurikova, T. (2009). Beta-glucans in higher fungi and their health effects. Nutrition Reviews, 67(11), 624-631. https://doi.org/10.1111/j.1 753-4887.2009.00230.x.

Roupas, P., Keogh, J., Noakes, M., Margetts, M., \& C., \& Taylor, P. (2012). The role of edible mushrooms in health evaluation of the evidence. Journal of Functional Foods, 4(4), 687-709. https://doi.org/10.1016/j.jff.2012.05.003.

Shengrong, S., Haining, Y., \& Xiaofeng, N. (2015). Production method of baked puffing shrimp chips. CN103431450B.

Shimizu, T. (2012). Food-derived bioactive peptides in the market. Food Proteins and Peptides, 1, 375-392. https://doi.org/10.1201/b11768-15.

Skov, A. R., Toubro, S., Ronn, B., Holm, L., \& Astrup, A. (1999). Randomized trial on protein vs carbohydrate in ad libitum fat reduced diet for the treatment of obesity. International Journal of Obesity and Related Metabolic Disorders, 23(5), 528-536. https://doi.org/10.1038/sj.ijo.0800867.

Speek, A. J., Schijver, J., \& Schreurs, W. H. P. (1985). Vitamin E composition of some seed oils as determined by high-performance liquid chromatography with fluorometric detection. Journal of Food Science, 50(1), 121-124. https:/ doi.org/10.1111/j.1365-2621.1985.tb13291.x.

Stea, T. H., Vik, F. N., Bere, E., Svendsen, M. V., \& Oellingrath, I. M. (2014). Meal pattern among Norwegian primary-school children and longitudinal associations between meal skipping and weight status. Public Health Nutrition, 15(2), 666-671.

Subbiah, K. A., \& Balan, V. (2015). A comprehensive review of tropical milk white mushroom. Mycobiology, 43(3), 184-194. https://doi.org/10.5941/MYCO.201 5.43.3.184.

Sung, H., Siegel, R. L., Rosenberg, P. S., \& Jemal, A. (2019). Emerging cancer trends among young adults in the USA: Analysis of a population-based cancer registry. The Lancet Public Health, 4(3), e137-e147. https://doi.org/10.1016/s24 68-2667(18)30267-6.

Synytsya, A., Míčková, K., Synytsya, A., Jablonský, l., Spěváček, J., Erban, V., ... Čopíková, J. (2009). Glucans from fruit bodies of cultivated mushrooms Pleurotus ostreatus and Pleurotus eryngii: Structure and potential prebiotic activity. Carbohydrate Polymers, 76(4), 548-555. https://doi.org/10.1016/j.ca rbpol.2008.11.021
Tu, J., Brennan, M., \& Brennan, C. (2020). An insight into the mechanism of interactions between mushroom polysaccharides and starch. Current Opinion in Food Science, 37, 17-25. https://doi.org/10.1016/j.cofs.2020.07.005.

USDA (2016). A guide to smart snacks in school. United States Department of Agriculture, 1, 1-10.

Valverde, M. E., Hernández-Pérez, T., \& Paredes-López, O. (2015). Edible mushrooms: Improving human health and promoting quality life. International Journal of Microbiology. 2015:367387. https://doi.org/10.1155/201 5/376387.

Yanbin, W., Hua, Q., Xiaoquing, T., Bentong, L., Liling, W., \& Yuchuan, Q. (2014). Ultrasonic-assisted freezing and vacuum frying production process of edible fungi. CN103892255A.

Zaheer, K., \& Akhtar, M. H. (2016). Potato production, usage, and nutrition-A review. Critical Reviews in Food Science and Nutrition, 56(5), 711-721. https:// doi.org/10.1080/10408398.2012.724479.

Zheng, H., Chen, J., \& Ahmad, I. (2017). Preservation of king oyster mushroom by the use of different fermentation processes. Journal of Food Processing and Preservation, 42(1), e13396. https://doi.org/10.1111/jppp.13396.

Zhihui, J., Wei, D., Jin, D., \& Huanliang, H. (2012). Preparation method of mushroom chip. CN101658291B.

Zhinian, Z. (2013). Crispy Pluorotus enyngii chip and preparation method thereof. CN103461440A

Zinian, Z. (2013). Milk-fragrance Pleurotus eryngii crisp chip and preparation method thereof. CN103461965A.

Zion Research (2016). Global savory snacks market will reach USD 108.5 billion by 2021. Zion Market Research. https://www.globenewswire.com/en/news-relea se/2016/12/07/895680/0/en/Global-Savory-Snacks-Market-will-reach-USD-1085-Billion-by-2021-Zion-Market-Research.html.

\section{Publisher's Note}

Springer Nature remains neutral with regard to jurisdictional claims in published maps and institutional affiliations.

Ready to submit your research? Choose BMC and benefit from:

- fast, convenient online submission

- thorough peer review by experienced researchers in your field

- rapid publication on acceptance

- support for research data, including large and complex data types

- gold Open Access which fosters wider collaboration and increased citations

- maximum visibility for your research: over $100 \mathrm{M}$ website views per year

At BMC, research is always in progress.

Learn more biomedcentral.com/submissions 